\title{
Synthesis of substituted Z-styrenes by Hiyama-type coupling of oxasilacycloalkenes: application to the synthesis of a 1-benzoxocane
}

\author{
James R. Vyvyan ", Courtney A. Engles, Scott L. Bray, Erik D. Wold, Christopher L. Porter \\ and Mikhail O. Konev
}

Full Research Paper

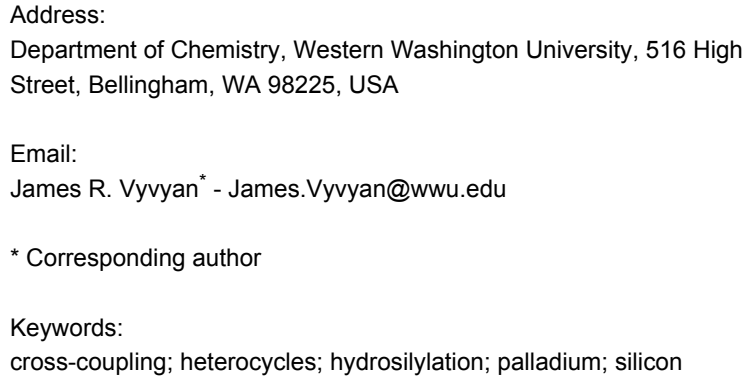

\author{
Beilstein J. Org. Chem. 2017, 13, 2122-2127. \\ doi:10.3762/bjoc.13.209 \\ Received: 24 June 2017 \\ Accepted: 22 September 2017 \\ Published: 11 October 2017 \\ Associate Editor: M. Rueping \\ (C) 2017 Vyvyan et al.; licensee Beilstein-Institut. \\ License and terms: see end of document.
}

\begin{abstract}
Several Hiyama cross-coupling reactions of oxasilacycloalkenes and aryl iodides are described that produce trisubstituted $Z$-styrenes in moderate to excellent yields. Both electron-rich and electron-poor aryl iodides are tolerated in the cross-coupling reaction. The oxasilacycloalkene coupling partners were prepared by ruthenium-catalyzed intramolecular anti-hydrosilylation of alkynols. One of the cross-coupling products was converted to a 1-benzoxocane, albeit in low yield, using an intramolecular Buchwald-Hartwig etherification. The cyclic ether produced contains the carbon skeleton of heliannuol A.
\end{abstract}

\section{Introduction}

The development of transition metal-catalyzed cross-coupling technologies over the last four decades revolutionized the synthetic chemistry. Indeed, the importance of Pd-catalyzed coupling was recognized with the 2010 Nobel Prize awarded to Heck, Negishi and Suzuki [1,2]. Developed somewhat later than the aforementioned methods and the couplings of organomagnesium and organotin reagents was the cross-coupling of silanes, pioneered by Hiyama [3,4] and siloxanes [5]. This versatile method has been extensively reviewed [6-8]. The cross-coupling of alkenyl silanols $[9,10]$ and oxasilacyclo- alkenes (cyclic siloxanes, cf. Figure 1) [6-8] is an excellent method to prepare stereodefined alkenes. The cyclic siloxanes can be prepared in a number of ways: hydrosilylation of alkynes [11-13], semihydrogenation of silyl alkynes [14], ring-closing metathesis (RCM) [15-21] and enyne metathesis [22,23].

We became interested in the cross-coupling of cyclic siloxanes in the context of preparing trisubstituted $Z$-styrenes for the synthesis of natural product targets [24]. Heliannuol A was the first member of a family of allelopathic [25-27] sesquiterpenoids 


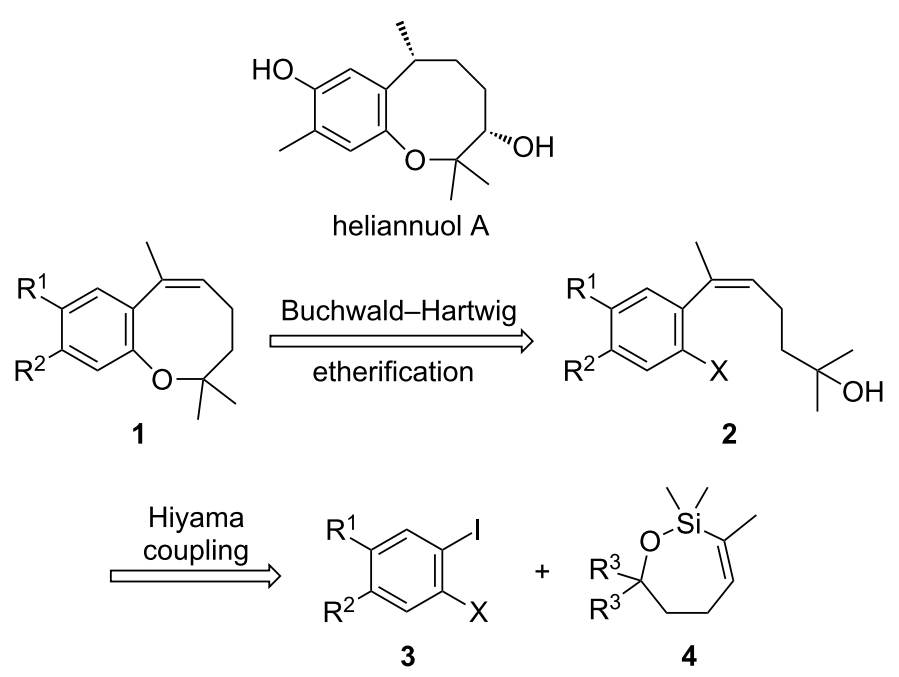

Figure 1: Retrosynthetic analysis of heliannuol $\mathrm{A}$.

isolated from the sunflower Helianthus annuus [28-33], and it contains an unusual benzoxocane moiety. Owing to their unusual structures and biological activity, the heliannuols have attracted significant attention from synthetic chemists. The various approaches to the heliannuols have recently been reviewed [34]. We have previously reported syntheses of heliannuols C, D, and E via intramolecular epoxide opening reactions $[35,36]$, but this approach did not translate well to the synthesis of heliannuol A. One of our alternative strategies for the synthesis of heliannuol A was an intramolecular Buchwald-Hartwig etherification of a $Z$-styrene derivative to provide a conformational constraint to facilitate the formation of the eight-membered ring [37]. The presence of the alkene reduces the conformational degrees of freedom in $\mathbf{2}$, thereby partially offsetting the entropic penalty of forming the eightmembered ring. We endeavored to test the strategy through the preparation of a simplified model compound 1 (Figure 1). We envisaged the precursor to the cycloetherification, 2 , would be prepared from the Hiyama-type cross-coupling of the appropriate aryl iodide $\mathbf{3}$ and the oxasilacycloalkene $\mathbf{4}$.

\section{Results and Discussion}

The oxasilacycloalkenes used in this study were readily prepared by intramolecular anti-hydrosilylation of alkynols 5-7 using the method reported by Ball and Trost (Scheme 1) $[12,13]$. Alkynol 5 was commercially available, $\mathbf{6}$ was readily prepared following literature procedures (see Experimental section), and alkynol 7 was, surprisingly, a new compound. The hydrosilylation reactions of 5-7 can be carried out on gram scales and generally produce high yields of the siloxane products after distillation. Siloxane 8a was isolated in more modest yield, however, probably owing to its volatility.

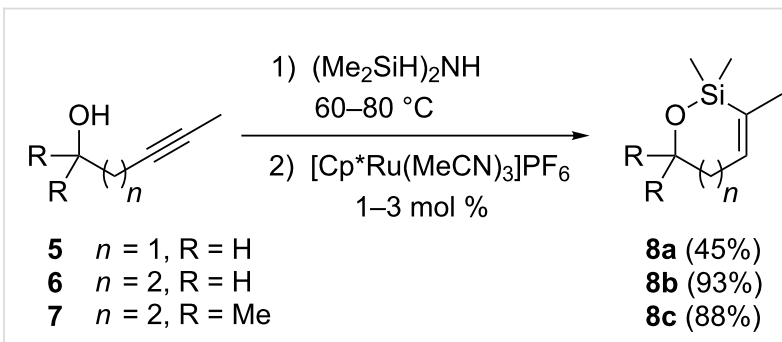

Scheme 1: Hydrosilylation of alkynols.

The siloxanes 8 participated efficiently in Hiyama-type crosscouplings with aryl iodides in the presence of $\mathrm{Pd}_{2}(\mathrm{dba})_{3}$ catalyst and tetrabutylammonium fluoride (TBAF, Table 1). Both electron-rich (Table 1, entries 1, 2, and 7) and electron-poor (Table 1, entries 5 and 6) iodides give coupled products in moderate to excellent yields. When multiple halogens were present, high selectivity for reaction at the aryl iodide was observed (Table 1, entries 3-5). Pyridyl iodide 22 also worked well in the cross-coupling (Table 1, entry 8).

Having prepared a number of substituted $Z$-styrenes, we next focused on the intramolecular Buchwald-Hartwig etherification [38-40] of bromoalcohol 15 to prepare eight-membered cyclic ether 24 (Table 2). The use of Pd(II) catalyst precursors with BINAP ligands and carbonate bases in toluene [38,39] was ineffective, returning significant amounts of unreacted starting material (Table 2, entry 1) or debrominated material 25 (Table 2, entry 2). The use of a bis(diphenylphosphino)ferrocenyl (dppf) ligand and a stronger base to irreversibly deprotonate the alcohol was similarly ineffective in both toluene and dioxane (Table 2, entry 3 ). Based on Hartwig's success with 
Table 1: Pd-catalyzed couplings of oxasilacycloalkenes with aryl iodides.

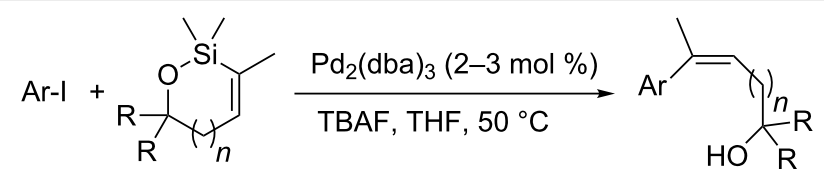

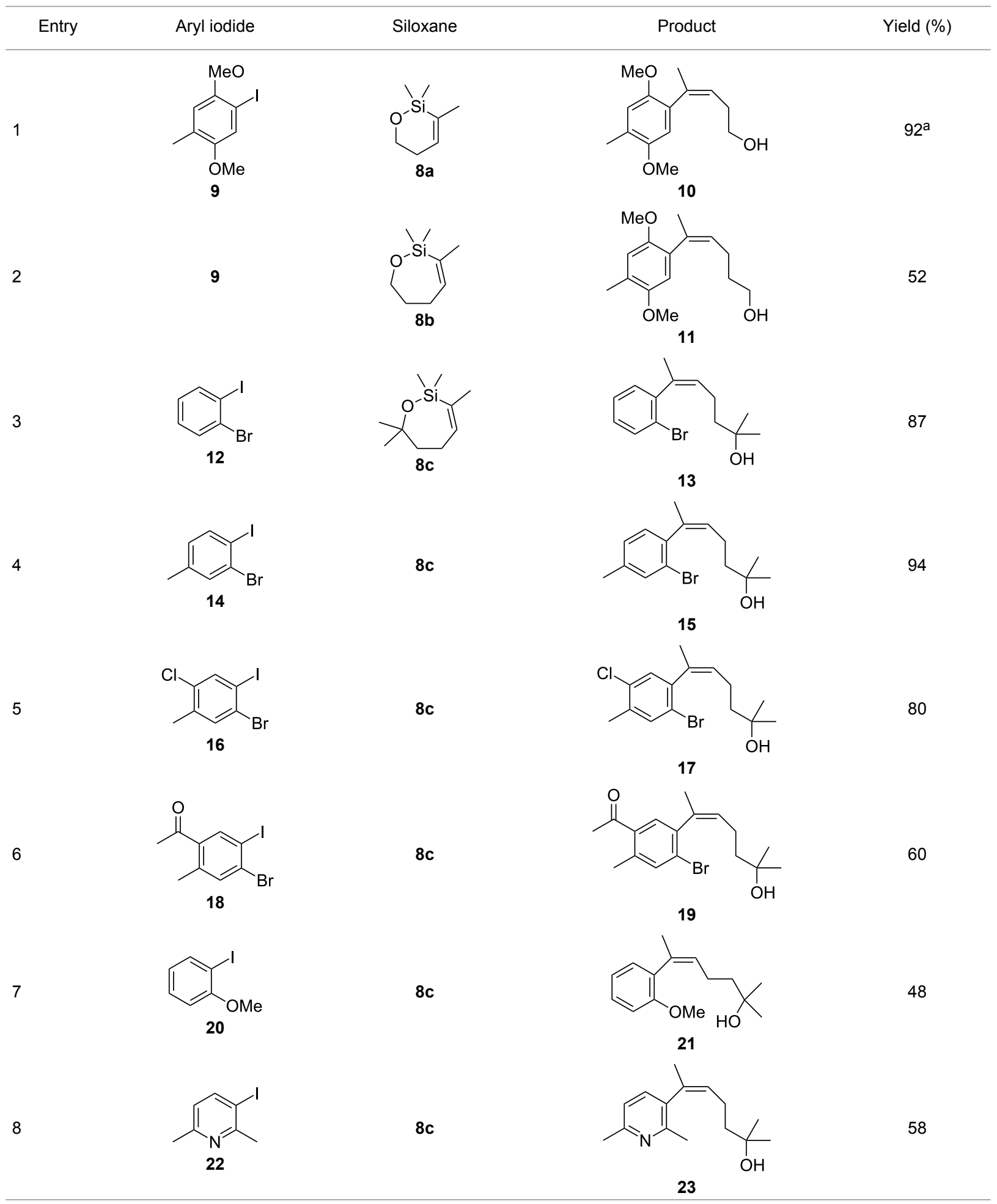

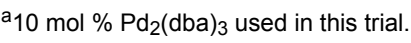


Table 2: Buchwald-Hartwig etherifications of bromoalcohol 15.

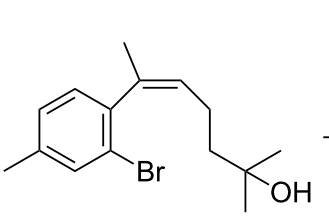

15

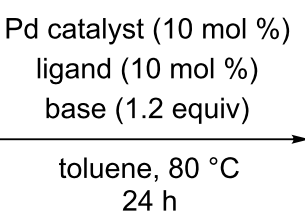

$24 \mathrm{~h}$

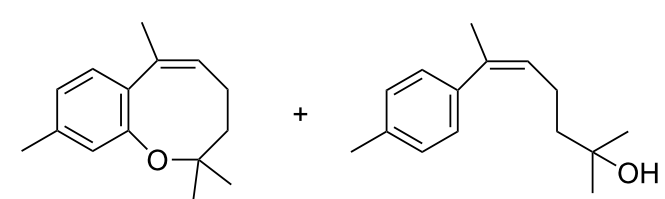

24
25

\begin{tabular}{|c|c|c|c|c|c|}
\hline \multirow[t]{2}{*}{ Entry } & \multirow[t]{2}{*}{ Pd catalyst } & \multirow[t]{2}{*}{ Ligand } & \multirow[t]{2}{*}{ Base } & \multicolumn{2}{|c|}{ Yield(\%) } \\
\hline & & & & 24 & 25 \\
\hline 1 & $\mathrm{Pd}(\mathrm{OAc})_{2}$ & tol-BINAP & $\mathrm{K}_{2} \mathrm{CO}_{3}$ & 0 & $0^{a}$ \\
\hline 2 & $\mathrm{Pd}(\mathrm{TFA})_{2}$ & tol-BINAP & $\mathrm{Cs}_{2} \mathrm{CO}_{3}$ & 0 & 21 \\
\hline 3 & $\mathrm{Pd}(\mathrm{OAc})_{2}$ & dppf & $\mathrm{NaH}$ & 0 & $45^{b}$ \\
\hline 4 & $\mathrm{Pd}(\mathrm{dba})_{2}$ & Q-Phos & $\mathrm{NaOt}-\mathrm{Bu}$ & 7 & 53 \\
\hline 5 & $\mathrm{Pd}(\mathrm{dba})_{2}$ & Q-Phos & $\mathrm{NaH}$ & 0 & 40 \\
\hline 6 & $\mathrm{Pd}_{2}(\mathrm{dba})_{3}$ & Q-Phos & $\mathrm{NaO} t-\mathrm{Bu}$ & 10 & 12 \\
\hline $7^{c}$ & $\mathrm{Pd}(\mathrm{dba})_{2}$ & Q-Phos & $\mathrm{NaOt}-\mathrm{Bu}$ & 6 & $21^{d}$ \\
\hline 8 & $\mathrm{Pd}(\mathrm{dba})_{2}$ & Q-Phos & DBU & 0 & $0^{e}$ \\
\hline
\end{tabular}

a73\% starting material recovered. bUsing dioxane as solvent gave a $32 \%$ yield of 25 . ${ }^{c}$ Microwave heating, $80{ }^{\circ} \mathrm{C}, 18 \mathrm{~h}$. ${ }^{\mathrm{d}} 25 \%$ starting material recovered. ${ }^{\mathrm{e}} 65 \%$ starting material recovered.

similar intramolecular etherifications to make five- and sixmembered rings [40], and our own preparation of an analogous seven-membered cyclic ether [41], we examined $\operatorname{Pd}(0)$ catalyst precursors with the Q-Phos ligand. The reaction with $\mathrm{Pd}(\mathrm{dba})_{2}$ with Q-Phos and sodium tert-butoxide produced cyclic ether $\mathbf{2 4}$ along with debrominated $\mathbf{2 5}$ as the major product (Table 2, entry 4). As before, irreversibly deprotonating the alcohol with sodium hydride was not productive (Table 2, entry 5). Using $\mathrm{Pd}_{2}(\mathrm{dba})_{3}$ as catalyst precursor increased the yield of 24 relative to the amount of $\mathbf{2 5}$ produced, but the overall yield of the cyclic ether was still low (Table 2, entry 6). Microwave heating was not helpful (Table 2, entry 7). The non-nucleophilic base DBU was not effective in promoting the cyclization, either (Table 2, entry 8 ). We observed small amounts of products arising from the dehydration of $\mathbf{1 5}$ in the ${ }^{1} \mathrm{H}$ NMR spectra of the crude reaction mixtures from these experiments, so we were reluctant to increase the reaction temperature further.

We also hydrogenated the conjugated olefin of $\mathbf{1 5}$ to increase the flexibility of the tether, in case the conformational constraint was actually hindering the cyclization, but no cyclic ether was observed when this material was subjected to Pd catalyst and base (not shown).

Hydrogenation of $\mathbf{2 4}$ over Pd/C gave 26, whose ${ }^{1} \mathrm{H}$ NMR spectrum matches that of the benzoxocane prepared by Pettus and co-workers [42] (Scheme 2), which was shown by them to be the now-refuted structure of helianane.

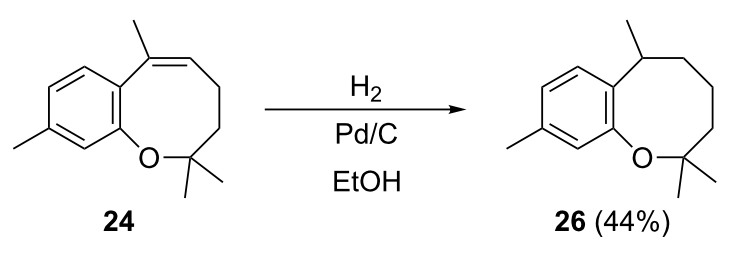

Scheme 2: Hydrogenation of benzoxocane 24 .

\section{Conclusion}

In summary, we have confirmed the Hiyama cross-coupling of cyclic siloxanes is an efficient route to $Z$-trisubstituted styrenes that are useful for the synthesis of natural product frameworks. Although yields are low under the conditions attempted, a proof of concept has been established in applying the Buchwald-Hartwig coupling to 15 , producing the benzoxocane 24, which contains the carbon skeleton of heliannuol A.

\section{Supporting Information}

\section{Supporting Information File 1}

Full experimental details and copies of ${ }^{1} \mathrm{H}$ and ${ }^{13} \mathrm{C}$ NMR spectra for all new compounds.

[http://www.beilstein-journals.org/bjoc/content/ supplementary/1860-5397-13-209-S1.pdf] 


\section{Acknowledgements}

This work was supported in part by the National Science Foundation (NSF CHE-0616995).

\section{References}

1. Johansson Seechurn, C. C. C.; Kitching, M. O.; Colacot, T. J.; Snieckus, V. Angew. Chem., Int. Ed. 2012, 51, 5062-5085. doi:10.1002/anie.201107017

2. de Meijere, A.; Bräse, S.; Oestreich, M., Eds. Metal-Catalyzed Cross-Coupling Reactions and More; Wiley-VCH: Weinheim, 2014. doi:10.1002/9783527655588

3. Hatanaka, Y.; Hiyama, T. J. Org. Chem. 1988, 53, 918-920. doi:10.1021/jo00239a056

4. Hiyama, T. J. Organomet. Chem. 2002, 653, 58-61. doi:10.1016/S0022-328X(02)01157-9

5. Mowery, M. E.; DeShong, P. J. Org. Chem. 1999, 64, 1684-1688. doi:10.1021/jo982463h

6. Denmark, S. E.; Sweis, R. F. Organosilicon Compounds in Cross-Coupling Reactions. In Metal-Catalyzed Cross-Coupling Reactions and More; de Meijere, A.; Bräse, S.; Oestreich, M., Eds.; Wiley-VCH: Weinheim, 2014; pp 475-532. doi:10.1002/9783527655588.ch7

7. Chang, W.-T.; Smith, R. C.; Regens, C. S.; Bailey, A. D.; Werner, N. S.; Denmark, S. E. Org. React. 2011, 75, 213-746. doi:10.1002/0471264180.or075.03

8. Sore, H. F.; Galloway, W. R. J. D.; Spring, D. R. Chem. Soc. Rev. 2012, 41, 1845-1866. doi:10.1039/C1CS15181A

9. Denmark, S. E.; Sweis, R. F. Org. Lett. 2002, 4, 3771-3774. doi:10.1021/ol026900x

10. Denmark, S. E.; Regens, C. S. Acc. Chem. Res. 2008, 41, 1486-1499. doi:10.1021/ar800037p

11. Denmark, S. E.; Pan, W. Org. Lett. 2002, 4, 4163-4166. doi:10.1021/ol026933c

12. Trost, B. M.; Ball, Z. T. J. Am. Chem. Soc. 2003, 125, 30-31. doi:10.1021/ja028766h

13. Trost, B. M.; Ball, Z. T.; Laemmerhold, K. M. J. Am. Chem. Soc. 2005, 127, 10028-10038. doi:10.1021/ja051578h

14. Elbert, B. L.; Lim, D. S. W.; Gudmundsson, H. G.; O'Hanlon, J. A.; Anderson, E. A. Chem. - Eur. J. 2014, 20, 8594-8598. doi:10.1002/chem.201403255

15. Ahmed, M.; Barrett, A. G. M.; Beall, J. C.; Braddock, D. C.; Flack, K.; Gibson, V. C.; Procopiou, P. A.; Salter, M. M. Tetrahedron 1999, 55, 3219-3232. doi:10.1016/S0040-4020(98)01135-1

16. Barrett, A. G. M.; Beall, J. C.; Braddock, D. C.; Flack, K.; Gibson, V. C.; Salter, M. M. J. Org. Chem. 2000, 65, 6508-6514. doi:10.1021/jo000690p

17. Denmark, S. E.; Yang, S.-M. Org. Lett. 2001, 3, 1749-1752. doi:10.1021/ol015950j

18. Denmark, S. E.; Yang, S.-M. Tetrahedron 2004, 60, 9695-9708. doi:10.1016/j.tet.2004.06.149

19. Xie, Q.; Denton, R. W.; Parker, K. A. Org. Lett. 2008, 10, 5345-5348. doi:10.1021/ol802063h

20. Volchkov, I.; Park, S.; Lee, D. Org. Lett. 2011, 13, 3530-3533. doi:10.1021/ol2013473

21. Volchkov, I.; Lee, D. J. Am. Chem. Soc. 2013, 135, 5324-5327. doi:10.1021/ja401717b

22. Miller, R. L.; Maifeld, S. V.; Lee, D. Org. Lett. 2004, 6, 2773-2776. doi:10.1021/ol049019n
23. Kim, H.; Lee, C. J. Am. Chem. Soc. 2005, 127, 10180-10181. doi:10.1021/ja052775j

24. Denmark, S. E.; Liu, J. H.-C. Angew. Chem., Int. Ed. 2010, 49 , 2978-2986. doi:10.1002/anie.200905657

25. Vyvyan, J. R. Tetrahedron 2002, 58, 1631-1646. doi:10.1016/S0040-4020(02)00052-2

26. Macías, F. A.; Molinillo, J. M. G.; Chinchilla, D.; Galindo, J. C. G. Heliannanes-a structure-activity relationship (SAR) study. In Allelopathy: chemistry and mode of action of allelochemicals; Macías, F. A.; Galindo, J. C. G.; Molinillo, J. M. G.; Cutler, H. G., Eds.; CRC Press: Boca Raton, 2004; pp 103-124.

27. Macías, F. A.; Varela, R. M.; Torres, A.; Molinillo, J. M. G. J. Chem. Ecol. 2000, 26, 2173-2186. doi:10.1023/A:1005524601019

28. Macías, F. A.; Varela, R. M.; Torres, A.; Molinillo, J. M. G.; Fronczek, F. R. Tetrahedron Lett. 1993, 34, 1999-2002. doi:10.1016/S0040-4039(00)91986-5

29. Macías, F. A.; Molinillo, J. M. G.; Varela, R. M.; Torres, A.; Fronczek, F. R. J. Org. Chem. 1994, 59, 8261-8266. doi:10.1021/j000105a052

30. Macías, F. A.; Varela, R. M.; Torres, A.; Molinillo, J. M. G. Tetrahedron Lett. 1999, 40, 4725-4728. doi:10.1016/S0040-4039(99)00833-3

31. Macías, F. A.; Varela, R. M.; Torres, A.; Molinillo, J. M. G. J. Nat. Prod. 1999, 62, 1636-1639. doi:10.1021/np990249y

32. Macías, F. A.; Torres, A.; Galindo, J. L. G.; Varela, R. M.; Álvarez, J. A.; Molinillo, J. M. G. Phytochemistry 2002, 61, 687-692. doi:10.1016/S0031-9422(02)00370-9

33. El Marsni, Z.; Torres, A.; Varela, R. M.; Molinillo, J. M. G.; Casas, L.; Mantell, C.; Martinez de la Ossa, E. J.; Macías, F. A. J. Agric. Food Chem. 2015, 63, 6410-6421. doi:10.1021/acs.jafc.5b02261

34. Chen, K.; Li, Y.; Du, Z.; Tao, Z. Synth. Commun. 2015, 45, 663-691. doi:10.1080/00397911.2014.979948

35. Vyvyan, J. R.; Looper, R. E. Tetrahedron Lett. 2000, 41, 1151-1154. doi:10.1016/S0040-4039(99)02284-4

36. Vyvyan, J. R.; Oaksmith, J. M.; Parks, B. W.; Peterson, E. M. Tetrahedron Lett. 2005, 46, 2457-2460. doi:10.1016/j.tetlet.2005.02.053

37. Werner, E. W. W. M. S. Ph.D. Thesis, Western Washington University, Bellingham, WA, 2007.

38. Torraca, K. E.; Huang, X.; Parrish, C. A.; Buchwald, S. L. J. Am. Chem. Soc. 2001, 123, 10770-10771. doi:10.1021/ja016863p

39. Vorogushin, A. V.; Huang, X.; Buchwald, S. L. J. Am. Chem. Soc. 2005, 127, 8146-8149. doi:10.1021/ja050471r

40. Kataoka, N.; Shelby, Q.; Stambuli, J. P.; Hartwig, J. F. J. Org. Chem. 2002, 67, 5553-5566. doi:10.1021/jo025732j

41. Vyvyan, J. R.; Wold, E. D.; Bray, S. L. unpublished results.

42. Green, J. C.; Jiménez-Alonso, S.; Brown, E. R.; Pettus, T. R. R. Org. Lett. 2011, 13, 5500-5503. doi:10.1021/ol2022214 


\section{License and Terms}

This is an Open Access article under the terms of the Creative Commons Attribution License

(http://creativecommons.org/licenses/by/4.0), which permits unrestricted use, distribution, and reproduction in any medium, provided the original work is properly cited.

The license is subject to the Beilstein Journal of Organic Chemistry terms and conditions:

(http://www.beilstein-journals.org/bjoc)

The definitive version of this article is the electronic one which can be found at:

doi:10.3762/bjoc.13.209 